\title{
Photoelectrodes with titanate nanotubes sensitized by mesoporphyrin derivative from cashew nut shell
}

\author{
Antonio Paulo Santos Souza ${ }^{1}$, Ana Fabíola Leite Almeida ${ }^{2}$,Leila de Souza Conegero ${ }^{3}$, \\ Bartolomeu Cruz Viana ${ }^{4}$, Odair Pastor Ferreira ${ }^{3}$, Francisco Klayton Marques de Alencar ${ }^{2}$, \\ Selma Elaine Mazzetto ${ }^{5}$, Pierre Basílio Almeida Fechine ${ }^{6}$, Manuel Pedro Fernandes Graça ${ }^{7}$, \\ Francisco Nivaldo Aguiar Freire ${ }^{2}$
}

\author{
${ }^{1}$ Department of Engineering and Materials Science, Ceará Federal University - UFC CEP: 60455-900, Fortaleza, Ceará, \\ Brazil. \\ ${ }^{2}$ LAFFER - Thin Films Laboratory in Renewable Energy, Mechanics Engineering Department, CEP: 60455-900, Ceará \\ Federal University, Fortaleza, Fortaleza, Ceará, Brazil. \\ ${ }^{3}$ LaMFA - Functional Materials Laboratory Advanced, Department of Physics, Universidade Federal do Ceará, UFC, \\ CEP: 60440-554, Fortaleza, Ceará, Brazil. \\ ${ }^{4}$ Department of Physics, Piauí Federal University, UFPI, CEP: 64049-550, Teresina, Piauí, Brazil. \\ ${ }^{5}$ Ceará Federal University, Centro de Ciências - Department of Organic and Inorganic Chemistry- CEP: 60455-760, For- \\ taleza, Ceará, Brazil. \\ ${ }^{6}$ Grupo de Química de Materiais Avançados (GQMAT), Departamento de Química Analítica e Físico-Química, Univer- \\ sidade Federal do Ceará, UFC, CEP: 60455-760, Fortaleza, Ceará, Brazil. \\ ${ }^{7} \mathrm{i} 3 \mathrm{~N}$ and Physics Department, Aveiro University, Campus Universitário de Santiago, Aveiro, Aveiro, Portugal. \\ e-mail: Antonio.souza@fisica.ufc.br, anfaleal@yahoo.com.br, nivaldo@ufc.br, klayton.eq@gmail.com, leilaconege- \\ ro@ fisica.ufc.br, opferreira@fisica.ufc.br,mpfg@ua.pt, bartolomeu@ufpi.edu.br, selma@ufc.br, fechine@ufc.br.
}

\section{ABSTRACT}

Titanate nanotubes (TiNTs) with the chemical composition $\mathrm{Na}_{2} \mathrm{Ti}_{3} \mathrm{O}_{7} \cdot \mathrm{nH}_{2} \mathrm{O}(\mathrm{NaTiNT})$ were obtained through a hydrothermal method in highly alkaline medium. Protonated titanates nanotubes (H-TiNTs), with the composition $\mathrm{H}_{2} \mathrm{Ti}_{3} \mathrm{O}_{7} \cdot \mathrm{nH}_{2} \mathrm{O}$, were prepared by ion exchange reaction through a suspension of $\mathrm{Na}_{2} \mathrm{Ti}_{3} \mathrm{O}_{7} \cdot \mathrm{nH}_{2} \mathrm{O}$ nanotubes in $\mathrm{HCl}$ medium, promoting the exchange of $\mathrm{Na}^{+}$ions by $\mathrm{H}^{+}$. Both $\mathrm{Na}_{2} \mathrm{Ti}_{3} \mathrm{O}_{7} \cdot \mathrm{nH}_{2} \mathrm{O}$ and $\mathrm{H}_{2} \mathrm{Ti}_{3} \mathrm{O}_{7} \cdot \mathrm{nH}_{2} \mathrm{O}$ products, as well the $\mathrm{TiO}_{2}$ used as raw material for the nanotubes processing, were used as starting material for the solar cells photoelectrodes sensitized using mesoporphyrin extracted from a precursor of cashew nut shell. Exposing the NaTiNT sample to solar radiation of $1258 \mathrm{~W} / \mathrm{m}^{2}$, a short-circuit current density $\left(\mathrm{I}_{\mathrm{SC}}\right)$ of $13 \mu \mathrm{A} / \mathrm{cm}^{2}$ and an open-circuit voltage $\left(\mathrm{V}_{\mathrm{OC}}\right)$ of $370 \mathrm{mV}$ were registered and, a current density of $7.6 \mu \mathrm{A} / \mathrm{cm}^{2}$ and a voltage of $256 \mathrm{mV}$ for the prototype cell based on H-TiNTs. A current density of 1.1 $\mu \mathrm{A} / \mathrm{cm}^{2}$ and an open-circuit voltage of $1.6 \mathrm{mV}$ were obtained for the cell using $\mathrm{TiO}_{2}$ as electrode.

Keywords: Titanate Nanotubes. Ionic exchange. Mesoporphyrin. Dye-sensitized solar cell.

\section{INTRODUCTION}

In the last years a large number of scientific reports about new materials for dye sensitized solar cells (DSSCs) have been published. Among these materials, unidimensional nanostructures have received particular attention due to their ability of creating shortcut-paths for the electrons, promoting the electron diffusion process [1-4].

YE et al. [5] recently showed the efficiency analysis of DSSC with electrodes formed by $\mathrm{TiO}_{2}$ nanotubes, which were prepared from $\mathrm{Ti}$ anodized sheets. It presents a 7.75\% of efficiency, using N719 as sensitizer [5]. KUANG et al. [6] revealed a efficiency value of 7.92\% in solar cells based on double layers of $\mathrm{TiO}_{2}$ nanoribbons. LAW et al. [7] showed that $\mathrm{ZnO}$ nanoribbons, with a diameter of approximately $130 \mathrm{~nm}$, used as photoelectrode on a DSSC present an electronic diffusion coefficient almost three orders of magnitude higher than the $\mathrm{TiO}_{2}$ nanoribbons. For the titanate nanotubes with higher dye adsorption area and higher nanostructure organization, the electron diffusion coefficient was $0.05-0.5 \mathrm{~cm}^{2} / \mathrm{s}$. This coefficient for the $\mathrm{TiO}_{2}$ film was $5 \times 10^{-5} \mathrm{~cm}^{2} / \mathrm{s}[7,8]$.

In addition to those nanostructures, titanate nanotubes have been widely reported in the literature. The combination of the elongated morphology with the mesoporous structure of the titanate nanotubes, which 
presents a high specific surface area, the efficient properties of ion exchange and relatively good proton and electron conductivity, make these nanostructures promising materials for various applications [9-12].

The use of titanate nanotubes in the construction of electrodes for dye-sensitized solar cells presents the advantage of larger cation absorption capacity of the dyes on the surface. For this, it is estimated that the colorant layer can have, in minimum, about 1000 molecules along the surface of each titanate nanotube. This dye monolayer will improve the effectiveness of radiation absorption which, combined with the elongated morphology of TiNTs should promote greater efficiency in the transportation and storage of electrons in DSSC [13,14].

The titanates may undergo structural changes by íon exchange (eg: H-TiNTs), doping or through combination with elements which absorb in the visible range resulting in nanomaterials with improved performance [13-15].

In general, all of these nanomaterials showing different morphologies can be synthesized by various methods such as the sol-gel [16], combustion [17], electrochemical deposition [18], chemical vapor deposition (CVD), physical vapour deposition (PVD), anodization, hydrothermal [19-22], through ultrasonication based method [11], among others. From these methods, in 1998, KASUGA et al [23] demonstrated a simple and efficient alternative route for the production of 1D nanostructures based on a hydrothermal treatment of $\mathrm{TiO}_{2}$ in a strongly alkaline solution $(\mathrm{NaOH})$. The resulting material presented nanostructures with an average out-diameter of $10 \mathrm{~nm}$ and average internal diameter of $5 \mathrm{~nm}$, and length higher than $100 \mathrm{~nm}$ [19, 24, 25].

Nowadays, in the DSSC, the photo-sensitizers dyes that show better results in terms of conversion and long-term stability in nanostructures are compounds based on Ruthenium (II) complexes [26, 27]. However, the photovoltaic effect is also observed in several important biological molecules such as carotenes, chlorophylls and other porphyrins, phthalocyanines, etc [27-31]. DSSC cells, in laboratory conditions, can already generate about $20 \mathrm{~mA} / \mathrm{cm}^{2}$, which is related with maximum efficiencies between 11 [32] and $12.3 \%$ [33]. These cells present therefore an exceptional ratio between energy conversion efficiency and production costs. It must be mention that in those experimental conditions, the maximum open-circuit voltage (Voc) generated by $\mathrm{TiO}_{2}$ cell is around $0.7 \mathrm{~V}$.

In the present work, sodium titanate $\left(\mathrm{Na}_{2} \mathrm{Ti}_{3} \mathrm{O}_{7} \cdot \mathrm{nH}_{2} \mathrm{O}\right)$ and hydrogen titanate $\left(\mathrm{H}_{2} \mathrm{Ti}_{3} \mathrm{O}_{7} \cdot \mathrm{nH}_{2} \mathrm{O}\right)$ nanotubes powders were prepared, respectively, from the following synthesis methods: i) hydrothermal in a highly alkaline medium (NaTiNT); ii) ion exchange process (H-TiNTs). Both materials were developed in film form and used as parts of DSSC cells. In addition, the samples were characterized by transmission electron microscopy (TEM), scanning electron microscopy (SEM), Raman spectroscopy, X-ray diffraction (XRD) and ultraviolet-visible spectroscopy (UV-VIS). The electrical resistance was measured by four-point probe method, at room temperature. The results lead us to assume that this strategy can be very useful to increase the efficiency of DSSC cells or even for other photocatalytic processes.

\section{MATERIALS AND METHODS}

\subsection{Synthesis of titanate nanotubes}

The titanate nanotubes synthesis performed in this work was based on the method described by FERREIRA et al. [19], where the TiNTs preparation process differs from KASUGA method [23], by modifying the parameters time, temperature, precursor mass and washing process.

Typically, the NaTiNT, with chemical composition $\mathrm{Na}_{2} \mathrm{Ti}_{3} \mathrm{O}_{7} \cdot \mathrm{nH}_{2} \mathrm{O}$, were obtained from $\mathrm{TiO}_{2}$ (anatase) by hydrothermal method in highly alkaline medium [19]. $1.5 \mathrm{~g} \mathrm{TiO}_{2}$ anatase spherical powder ( $99.8 \%$ purity and $68 \mathrm{~nm}$ of diameter) from the manufacturer (Vetec) was suspended in a concentrated solution of $\mathrm{NaOH}(10 \mathrm{~mol} / \mathrm{L})$ and transferred to an autoclave where it remained for 24 hours at a temperature of $160 \pm 5$ ${ }^{\circ} \mathrm{C}$. After, the white solid was washed with deionized water until $\mathrm{pH}$ of the supernatant reaches a value between 11 and 12. The protonated nanotubes (H-TiNTs), with chemical composition $\mathrm{H}_{2} \mathrm{Ti}_{3} \mathrm{O}_{7} \cdot \mathrm{nH}_{2} \mathrm{O}$, were obtained from the suspension of $\mathrm{NaTiNT}$ in $\mathrm{HCl}$ solution $(0.1 \mathrm{~mol} / \mathrm{L})$. This suspension was magnetically stirred for $24 \mathrm{~h}$ to improve the ionic exchange reaction between $\mathrm{Na}$ and $\mathrm{H}$ ions. The last step was the washing of the result suspension, controlling the $\mathrm{pH}(\mathrm{pH}=7)$ using deionized water. All chemicals (reagent grade: SigmaAldrich, Dynamics and Vetec) were used as received, without further purification processes. All solutions were prepared with deionized water. 


\subsection{Fabrication of the photovoltaic cell}

The synthetized TiNTs powders, presented in the form of a white power lightweight compared to its precursor, Anatase. For the preparation of the pastes containing these nanostructures it was weighed $0.1921 \mathrm{~g}$, $0.1416 \mathrm{~g}$ and $0.3518 \mathrm{~g}$ of NaTiNT, H-TiNTs and $\mathrm{TiO}_{2}$, respectively. At the same time it was weighed silver powder in a quantity equivalent to $10 \%$ of the weighted value for $\mathrm{TiNTs}$ and $\mathrm{TiO}_{2}$. Silver will improve the adherence of the paste to the FTO $\left(\mathrm{F}-\mathrm{SnO}_{2}\right)$ cell substrate, due to the different charge polarities. Silver was blended to the TiNTs and $\mathrm{TiO}_{2}$ followed by addition of $0.623 \mathrm{ml}, 0.465 \mathrm{ml}$ and $0.357 \mathrm{ml}$ of acetic acid (PA glacial) and $0.168 \mathrm{ml}, 0.168 \mathrm{ml}$ and $0.168 \mathrm{ml}$ of Triton-x (Vetec), respectively for the samples NaTiNT, HTiNTs and $\mathrm{TiO}_{2}$. The resulting folders acquired a viscous grayish. Once the three mixtures were prepared it was necessary that the application area in glasses conductors was demarcated. For this we used tape for demarcating the desired region $\left(\sim 1 \mathrm{~cm}^{2}\right)$ and used a glass rod to spread the mixture over the marked surface. After deposition of the layers, the sample remain in a heater plate for 30 minutes at $100{ }^{\circ} \mathrm{C}$, in order to evaporate the excess of liquid, avoiding undesirable formations on the film surface and contribute to the film adhesion.

The NaTiNT, H-TiNTs and $\mathrm{TiO}_{2}$ nanostructures were separately deposited via doctor blading in nonconductive glass substrates, which were previously prepared with fluorine donated tin oxide layer, FTO, by spray-pyrolysis, forming the bottom electrode. The average sheet resistances of these FTO layers were $6.47 \pm$ $1.42 \Omega / \mathrm{sq}$. Each nanostructure received $0.201 \mathrm{~g}$ of mesoporphyrin (5,10,15,20-tetra-[4-(2-(3pentadecyl)phenoxy)ethoxy]phenylporphyrin). Mesoporphyrin was synthesized from an isolated precursor (cardanol) of the cashew nut shell liquid [34-36], in powder form and solubilized in $2.5 \mathrm{ml}$ of chloroform. The dye regenerator electrolyte was prepared by dissolving, in distilled water $0.5 \mathrm{~mol} / \mathrm{L}$, of potassium iodide (KI) and $0.05 \mathrm{~mol} / \mathrm{L}$ of iodine $\left(\mathrm{I}_{2}\right)$. As counter-electrode cell, a FTO glass with a graphite layer was used. Figure 1 shows, schematically, the entire PV cell.

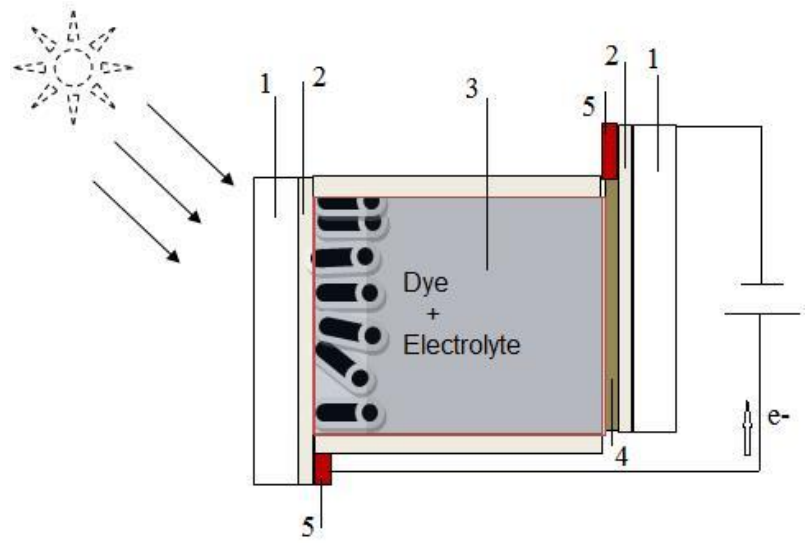

Figura 1: Solar cell diagram: (1) - Optical glass blades; (2) - FTO layer; (3) - Titanates nanotubes on the organic dye and electrolyte; (4) - Graphite layer; (5) - Electrical contacts.

\subsection{Structural and optical measurements}

$\mathrm{X}$-ray diffraction measurements were made in the nanotubes and $\mathrm{TiO}_{2}$ samples by using a XRD diffractometer, model D8 Advanced - Bruker with angular variation (2 $\theta$ ) between 5 and $70^{\circ}$, a step size of $0.02^{\circ}$, a step time of $10 \mathrm{~s}$, input and output slots of $0.2 \mathrm{~mm}$, and a current and voltage of $40 \mathrm{~mA}$ and $40 \mathrm{kV}$, respectively, applied in the copper ampoule $(\mathrm{Cu}-\mathrm{K} \alpha, 0.15406 \mathrm{~nm})$. Raman spectroscopy was also performed on the NaTiNT and $\mathrm{TiO}_{2}$ samples, using a LabRAM HR equipment - Horiba Scientific. The spectra was obtained in backscattering, using as excitation sources the $633 \mathrm{~nm}$ line of a He-Ne laser and the $785 \mathrm{~nm}$ line of a diode laser. For the samples H-TiNTs a $532 \mathrm{~nm}$ laser line was used. The Raman spectra were collected using a 600 $\mathrm{gr} / \mathrm{mm}$ diffraction grating. Reflectance measurements were performed on a spectrophotometer Ocean optics USB 2000+ brand in reflection mode. 


\subsection{Morphological measurements}

For the morphological characterization of the powder samples NaTiNT and H-TiNTs, the powders were attached to a carbon tape and after covered by a gold-platinum sputtered film for the scanning electron microscopy (SEM) measurements on a Mark Phillips microscope. The measurement conditions were: working distance (WD) of $11.0 \mathrm{~mm}$ and accelerating voltage of $20 \mathrm{kV}$. Transmission electron microscopy (TEM) images were obtained using a FEI-Tecnai 200 setup operating with a $200 \mathrm{kV}$. The TEM samples were prepared by dropping an aqueous suspension of sample powder on a holey carbon-coated copper grid and letting the water evaporate at room temperature. For the morphological characterization of the NaTiNT, H-TiNTs and $\mathrm{TiO}_{2}$ layers deposited on the FTO conductive glass besides SEM analysis measurements on a Mark Phillips microscope.

\subsection{Electrical measurements}

For the three different cells the short-circuit currents density (Isc) and the open-circuit voltages (Voc) were collected in the presence of light and in dark conditions. For the measurements in the presence of light, it was been used the natural sun light, which incident radiation (Pinc) presents an average value of $1258 \mathrm{~W} / \mathrm{m}^{2}$ (table 1), measured by a solar power meter RIGOL SP-2000.

\section{RESULTS AND DISCUSSION}

\subsection{X-Ray Diffraction and Raman Spectroscopy}

The structural analysis of the $\mathrm{TiO}_{2}$ and TiNTs samples was performed on dry powder form, by XRD. Figure 2(a) shows the results, confirming the anatase phase (ICDS 024276) for $\mathrm{TiO}_{2}$ and the formation of TiNTs with the orientations of crystalline planes [19], respectively. The XRD pattern of the H-TiNTs sample is very similar to the one of NaTiNT because there is no structural change in the ion exchange but only approximations between the walls of the tubes [19].

(a)

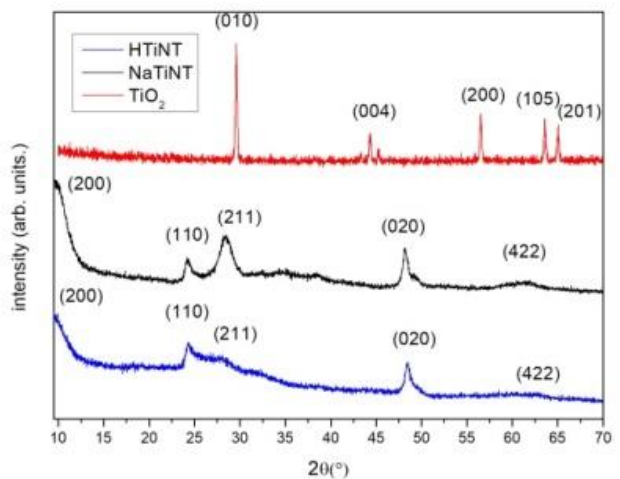

(b)

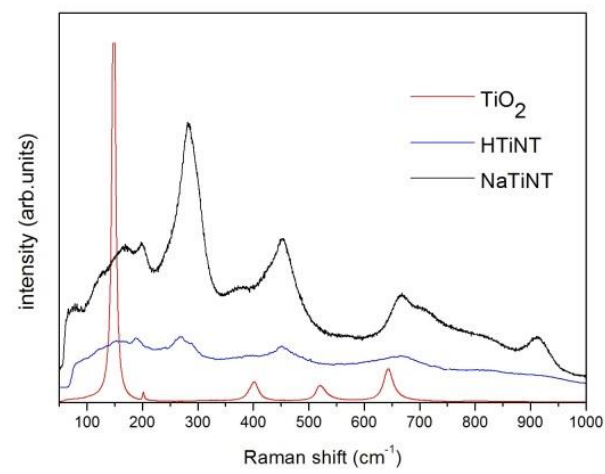

Figure 2: (a) XRD patterns of the $\mathrm{TiO}_{2}$ and NaTiNT powders; (b) Raman spectra of the NaTiNT, H-TiNTs and $\mathrm{TiO}_{2}$ powders samples.

Figure 2(b) shows the Raman spectra of both $\mathrm{TiO}_{2}$ and TiNTs samples. Comparing those spectra with the one of the staring material (anatase), it is suggested a complete conversion of the starting $\mathrm{TiO}_{2}$ into NaTiNT and to H-TiNTs phases. Several studies about the vibrational properties of titanate nanotubes [24, 25, 37] have helped authors to adopt the trititanate phase as the forming structure of these nanomaterials, however with the addition of water in the interlayer region, and therefore presenting the general chemical formula of $\mathrm{Na}_{2-\mathrm{x}} \mathrm{H}_{\mathrm{x}} \mathrm{Ti}_{3} \mathrm{O}_{7} \cdot \mathrm{nH}_{2} \mathrm{O}$. To confirm the purity and homogeneity degree of the titanate nanotubes, Raman spectroscopy was performed in four different regions (R1, R2, R3 and R4) and the result is shown in Figure 3. As it can be seen there is no difference among the spectra indicating a homogeneous morphological distribution. 


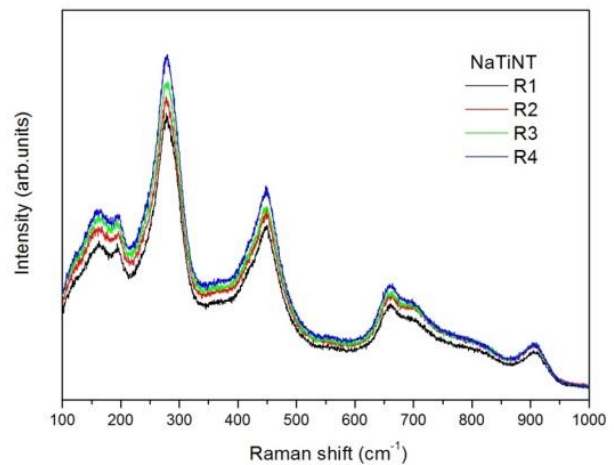

Figure 3: Raman spectra of the NaTiNT sample in 4 different regions.

\subsection{SEM and TEM of TiNTs in the form of powder}

These TiNTs of the powder samples were analyzed by SEM for detection of tubular morphologies, as shown in Figures 4(a) and 4(b). Figure 5 shows the TEM image of sodium titanate nanotubes (NaTiNT) as synthesized. From SEM and TEM images it is possible to confirm that these nanostructures have a tubular morphology, with an out-diameter close to $10 \mathrm{~nm}$ and average inner diameter close to $5 \mathrm{~nm}$. The maximum length is about $100 \mathrm{~nm}$ [24, 25]. From figure 4(a), it can be seen that the NaTiNT tubes tend to agglomerate in random directions. Between these clusters there are air gaps which make these nanostructures very porous, which is an important feature for application in DSSC.

(a)

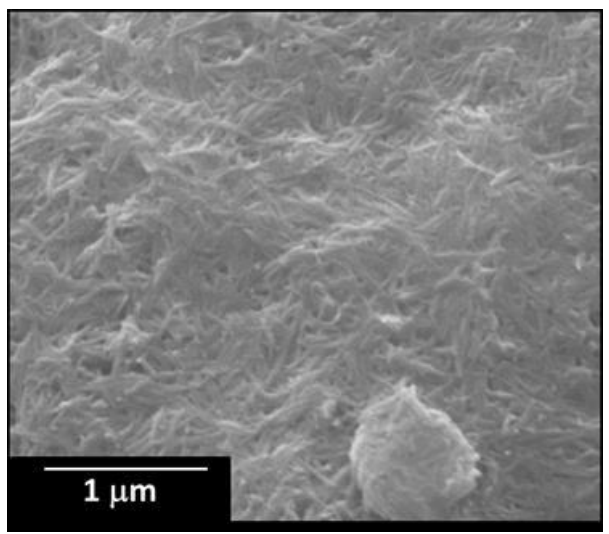

(b)

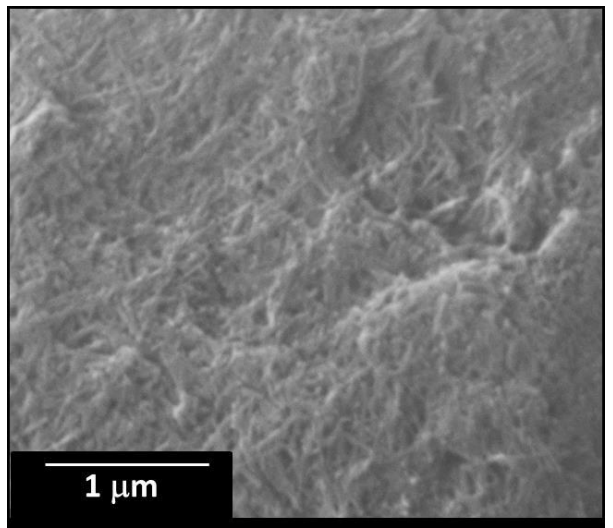

Figure 4: SEM micrograph of the powder samples: (a) NaTiNT; (b) H-TiNTs.

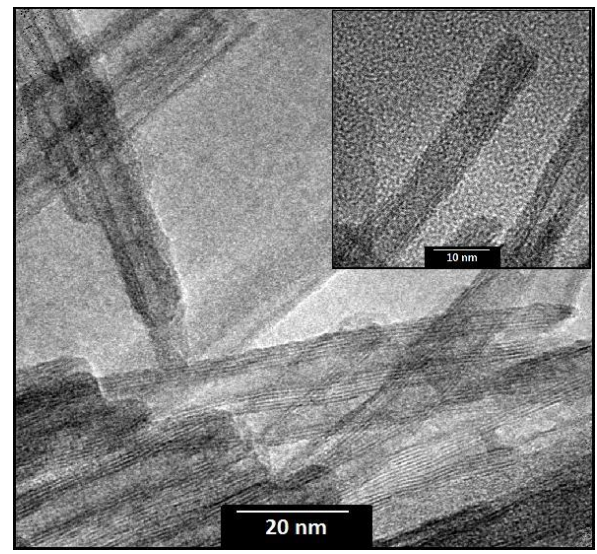

Figure 5: Transmission electron micrograph of NaTiNT. 


\subsection{Characterization of the layers by Reflectance and SEM}

Reflectance measurements of the conductive glass in the ultraviolet-visible (UV-vis) and near infrared (300 $\mathrm{nm}-900 \mathrm{~nm}$ ) region were made and result is presented in Figure 6. For wavelengths of 430 and $560 \mathrm{~nm}$, the glass with FTO presented reflectance values of $12 \%$ and $10 \%$, respectively. The non-conductive glass reflected $5.2 \%$, at $430 \mathrm{~nm}$, and $5.0 \%$ at $560 \mathrm{~nm}$. This result suggests the use of sensitizers that absorb in this spectral region, considering that there will be a greater transmission of visible light in these regions. Figure 7 shows the SEM image of the FTO conductive film, with a thickness of $\sim 250 \mathrm{~nm}$.

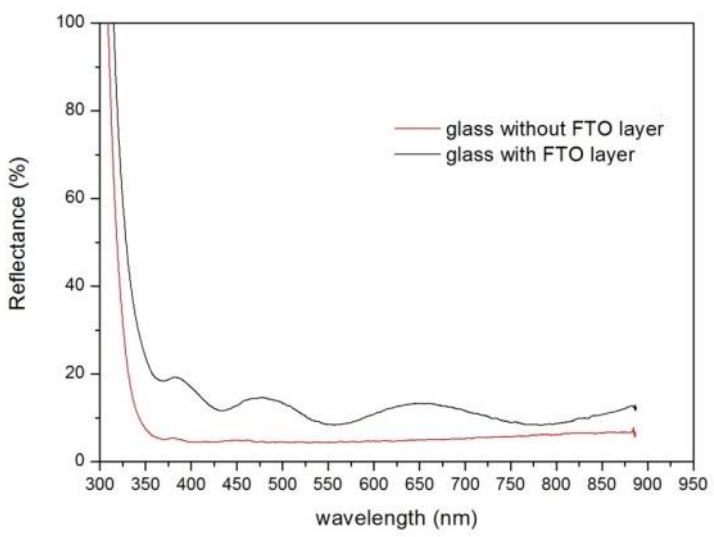

Figure 6: Reflectance spectra of the glass substrate, with and without the conductive FTO layer.

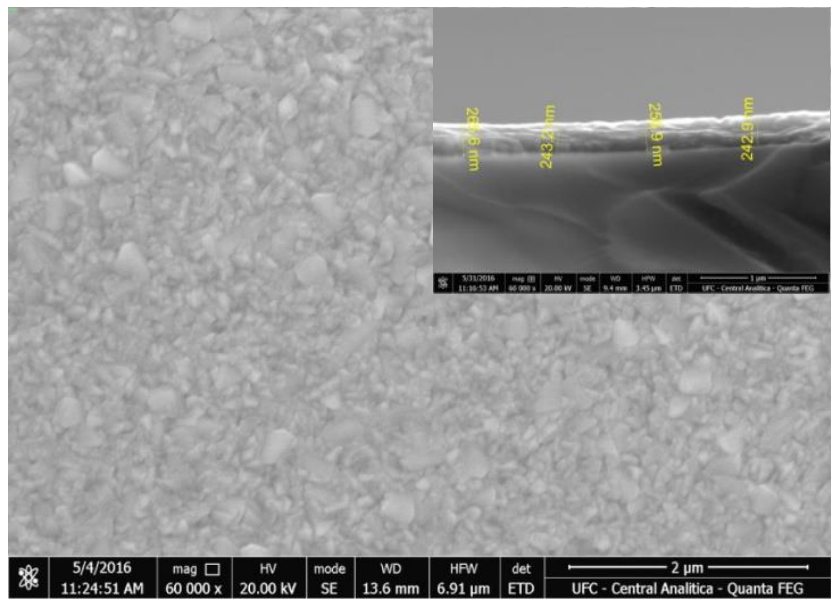

Figure 7: Surface SEM micrograph of the glass substrate with the FTO layer. Inset shows the film thickness.

Figure 8(a) shows the SEM images of the NaTiNT layer. It can be seen that the layer has a high roughness is irregular and with open porosity. The low regularity is due to the manual form of deposition which contributed to the formation of agglomerates. The thickness of the NaTiNT layer was about $18.4 \mu \mathrm{m}$. Figure 8(b) shows the surface micrographs of the $\mathrm{TiO}_{2}$ sample. It can be observed a compact and less porous layer when compared to the NaTiNT, but with some gaps and cracks. Thus, this $\mathrm{TiO}_{2}$ layer will have a lower dye adsorption capacity when compared with the titanate nanotubes. The $\mathrm{TiO}_{2}$ layer thickness is about 10.4 $\mu \mathrm{m}$. Figure 9 shows the reflectance curves of the NaTiNT and $\mathrm{TiO}_{2}$ samples with and without mesoporphyrin, extracted from a precursor of cashew nut shell. From Figure 9(a) it can be noted that all reflectance peaks of the NaTiNT sample with mesoporphyrin are less intense than the peaks of the same sample but without mesoporphyrin. This proves that mesoporphyrin acts as a sensitizing dye, causing an improvement of the NaTiNT layer to absorb the radiation in the $400-650 \mathrm{~nm}$ region $[19,20]$. From figure 9 (b) it can be noticed 
that all the reflectance peaks of the $\mathrm{TiO}_{2}$ layer with mesoporphyrin are less intense than the peaks of the $\mathrm{TiO}_{2}$ layer without mesoporphyrin. The large reductions in the reflectance peaks near $430 \mathrm{~nm}, 550 \mathrm{~nm}$ and $620 \mathrm{~nm}$ are therefore related with a higher radiation absorption in those regions.

(a)

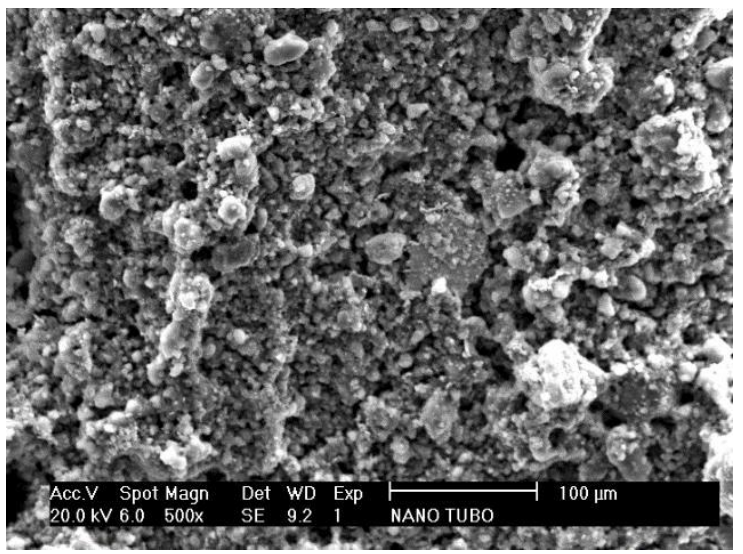

(b)

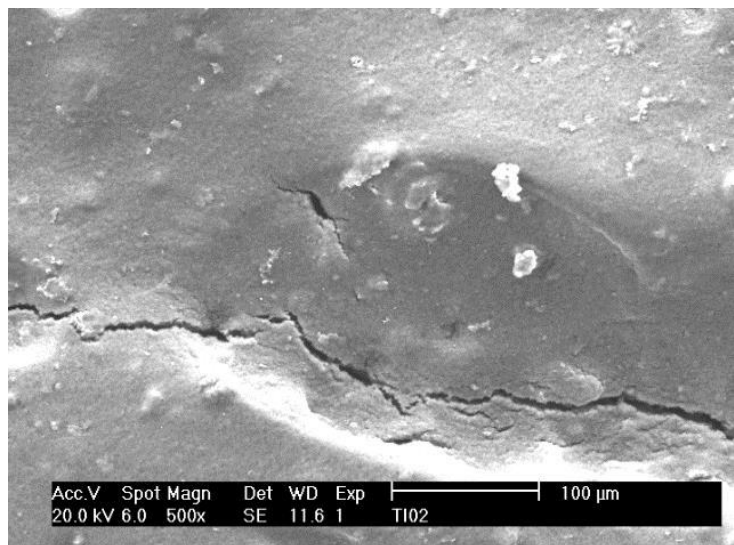

Figure 8: Surface SEM micrographs of the layers: (a) NaTiNT sample; (b) $\mathrm{TiO}_{2}$ sample.

(a)

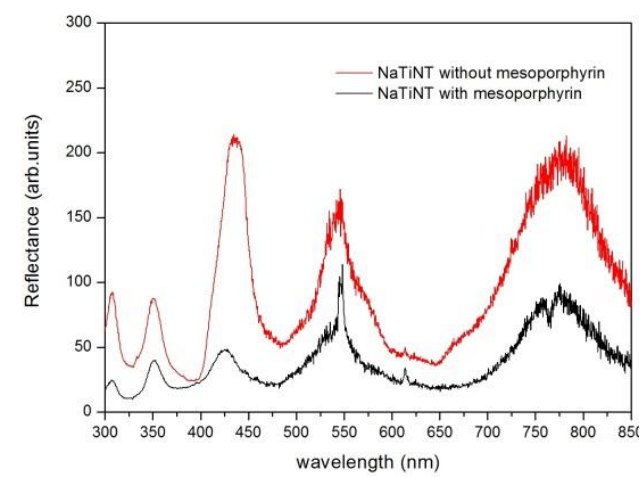

(b)

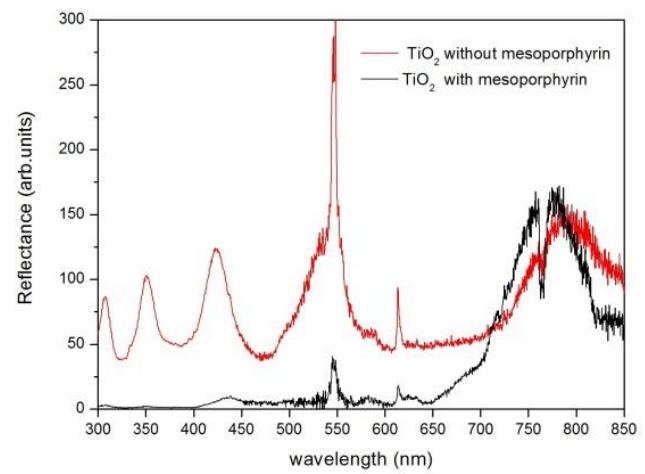

Figure 9: Reflectance of the layers: (a) NaTiNT sample with and without mesoporphyrin; (b) $\mathrm{TiO}_{2}$ sample with and without mesoporphyrin.

\subsection{Electrical characterization of solar cells}

The photoelectric results, at room temperature, are presented in table 1. As one can see the photocurrent measurement in the presence and absence of light, shows the photovoltaic effect. In the presence of light, with an incident radiation of $1258 \mathrm{~W} / \mathrm{m}^{2}$, it was verified that NaTiNT is the sample with the maximum energy conversion efficiency due to the higher values of $\mathrm{I}_{\mathrm{SC}}$ and $\mathrm{V}_{\mathrm{OC}}$. The higher conversion of the solar radiation in the NaTiNT sample can be associated with the high porosity level, which promotes a better dye absorption and possibly a larger collection of electrons. 
Table 1: Electrical characteristics of the cells samples.

\begin{tabular}{l|l|l|l}
\hline $\begin{array}{l}\text { ELECTRICAL } \\
\text { PARAMETER }\end{array}$ & $\begin{array}{l}\text { SAMPLE WITH } \\
\text { NaTiNT }\end{array}$ & $\begin{array}{l}\text { SAMPLE WITH } \\
\text { H-TiNTs }\end{array}$ & $\begin{array}{l}\text { SAMPLE WITH } \\
\text { TiO }_{2}\end{array}$ \\
\hline Resistance & $36 \mathrm{k} \Omega$ & $53 \mathrm{k} \Omega$ & $430 \Omega$ \\
\hline$I_{S C}$ (Light) & $13 \mu \mathrm{A} / \mathrm{cm}^{2}$ & $7.6 \mu \mathrm{A} / \mathrm{cm}^{2}$ & $1.1 \mu \mathrm{A} / \mathrm{cm}^{2}$ \\
\hline$I_{S C}$ (Dark) & $0.1 \mu \mathrm{A} / \mathrm{cm}^{2}$ & $0.0 \mu \mathrm{A} / \mathrm{cm}^{2}$ & $0.0 \mu \mathrm{A} / \mathrm{cm}^{2}$ \\
\hline$V_{O C}$ (Light) & $370 \mathrm{mV}$ & $256 \mathrm{mV}$ & $1.6 \mathrm{mV}$ \\
\hline$V_{O C}$ (Dark) & $0.2 \mathrm{mV}$ & $1.1 \mathrm{mV}$ & $0.3 \mathrm{mV}$ \\
\hline$P_{\text {inc }}$ & $1258 \mathrm{~W} / \mathrm{m}^{2}$ & $1258 \mathrm{~W} / \mathrm{m}^{2}$ & $1258 \mathrm{~W} / \mathrm{m}^{2}$ \\
\hline FF (Fill Factor) & 0.38 & 0.38 & 0.36 \\
\hline$\eta(\%)$ Efficiency & $1.45 \times 10^{-5}$ & $5.88 \times 10^{-6}$ & $5.04 \times 10^{-9}$ \\
\hline & & &
\end{tabular}

\section{CONCLUSIONS}

The nanotubes synthesized showed highly porous characteristics, which make them strong candidates for application in DSSC. There was a low homogeneity and adherence of the NaTiNT, H-TiNTs and $\mathrm{TiO}_{2}$ to the FTO substrate, which is explained by the deposition technique used. In the reflectance analysis, the layers with mesoporphyrin began to absorb more radiation in the visible region. This is due to the presence of the dye that photosensitizes the nanostructures in the visible spectrum. The cell whose photoelectrode is composed of NaTiNT showed, under natural light, better short-circuit current density and open-circuit voltage values. The results lead to believe that the more porous NaTiNT layer is, better is the adsorption of the dye and hence a larger photoelectrochemical effect. In spite of the higher electrical resistances for the devices containing TiNTs, these were the ones that had better photovoltaic performance. This suggests that the high porosity of these materials contribute strongly to the adsorption of the dye and favors the production of electric current.

\section{ACKNOWLEDGEMENTS}

The authors are grateful to Central Analítica UFC/CT-INFRA/MCTI-SISNANO/Pro-Equipamentos CAPES for providing the scanning electron microscopes. OPF and BCV acknowledge support from CAPESPROCAD 2013 Grant 183995 and thanks CETENE for TEM images. Grateful to Materials Characterization Laboratory, LACAM.) Acknowledge to I3N (UID/CTM/50025/2013).

\section{BIBLIOGRAPHY}

[1] QI, P., LIMIN, L., LIJUAN, Z., et al., "Dye sensitized solar cells using freestanding $\mathrm{TiO}_{2}$ nanotube arrays on FTO substrate as photoanode", Materials Chemistry and Physics, v.125, pp. 612-616, Feb. 2011.

[2] LI, Z., JIAGUO, Y., JIAJIE, F., et al., "Dye-sensitized solar cells based on ordered titanate nanotube films fabricated by electrophoretic deposition method", Electrochemistry Communications, v. 11, pp. 20522055, Aug. 2009.

[3] AIYING, P., LUNCHAO, X., HAIYAN, L., et al., "Efficient indoline dyes co-sensitized solar cells composed of titania nanorods", Electrochimica Acta, v. 94, pp. 92- 97, Apr. 2013.

[4] GIL-SUNG, K., HYUNG-KEE, S., GODBLE, V.P., et al., "Electrophoretic deposition of titanate nanotubes from commercial titania nanoparticles: Application to dye-sensitized solar cells", Electrochemistry Communications, v. 8 pp. 961-966, March 2006.

[5] YE M.D., XIN X.K., LIN C.J., et al., "High efficiency dye-sensitized solar cells based on hierarchically structured nanotubes", Nano Letters, v.11, pp. 3214, July 2011.

[6] WU W.Q., LIAO J.Y., CHEN H.Y., et al., "Dye-sensitized solar cells based on a double layered $\mathrm{TiO}_{2}$ photoanode consisting of hierarchical nanowire arrays and nanoparticles with greatly improved photovoltaic performance", Journal of Materials Chemistry v. 22, pp.18057, July 2012. 
[7] YELlA, A., LEE, H.W., TSAO, H.N., et al., "Porphyrin-Sensitized Solar Cells with Cobalt (II/III)Based Redox Electrolyte Exceed 12 Percent Efficiency”, Science, v. 334, pp. 629-634, Nov. 2011.

[8] ZHANG, Q., GUOZHONG, C., "Nanostructured photoelectrodes for dye-sensitized solar cells", Nano Today, v.6, pp. 91-109, Feb. 2011.

[9] TEREZA, B., DANIELA, P., WEI, W., et al., "Study of titanate nanotubes by X-ray and electron diffraction and electron microscopy", Materials characterization, v. 87, pp. 166 - 171, Jan.2014.

[10] TANAKA, K.,. "Photocatalytic degradation of mono, di and trinitro-phenol in aqueous $\mathrm{TiO}_{2}$ suspension", J. Mol. Catal., v. 122, July 1997.

[11] ZURBA, N.K., FERREIRA, J.M.F., "Core-Shells of $\mathrm{SrAl}_{2} \mathrm{O}_{4}$ :Ce(III), Ln Phosphor Coated by $\mathrm{TiO}_{2}$ Nanotube and Nanowire-Shaped Structures, Journal of Nanoengineering and Nanomanufacturing", v. 2, pp.1-9, 2012.

[12] HARA, K., SAYAMA, K., OHGA, Y., et al., "A coumarinderivative dye sensitized nanocrystalline $\mathrm{TiO}_{2}$ solar cell having a high solar-energy conversion efficiency up to 5.6\%", Chemical Communications, v. 6, pp. 569-570, Feb. 2001.

[13] YLHÄINEN, E. K., NUNES, M. R., SILVESTRE, A. J., et al., "Titania-free synthesis of titanates nanostructures", Sol. Stat. Sci., 2016.

[14] BAVYKIN, D. V., WALSH, F. C., "Elongated titanate nanostructures and their applications",Eur. J. Inorg. Chem.,v. 2009, pp. 977-997, Mar. 2009.

[15] XIAO, M. W., WANG, L. S., WU, Y. D., et al., "Preparation and characterization of CdS nanoparticles decorated into titanate nanotubes and their photocatalytic properties", Nanotechnology, v.19, pp.15706, Nov. 2007.

[16] BAIJU, K., "Effect of tantalum addition on anatase phase stability and photoactivity of aqueous sol-gel derived mesoporous titania", Journal of Molecular Catalysis A: Chemical, v.276, pp. 41-46, oct. 2007.

[17] SIVALINGAM, G., "Photocatalytic degradation of various dyes combustion synthesized nano anatase $\mathrm{TiO}_{2}$ ” Applied Catalysis B: Environmental, v. 48, pp. 83-93, Mar. 2004.

[18] ZHITOMIRSKY, I., "Cathodic electrosynthesis of titanium and ruthenium oxides", Materials Letters, v. 33, pp. 305-310, Jan. 1998.

[19] FERREIRA, O.P., "Unveiling the Structure and Composition of Titanium Oxide Nanotubes through Ion Exchange Chemical Reactions and Thermal Decomposition Processes", J. Braz. Chem. Soc., v. 17, n. 2, pp.393-402, Apr. 2006.

[20] EDISSON, M. J., BOJAN, A., MARINKOVIC, P., et al., "Characterization and thermal stability of cobalt-modified 1-D nanostructured trititanates", Journal of Solid State Chemistry v. 182, pp.172-181, Jan. 2009.

[21] DRESSELHAUS, M.S., LIN, Y.M., RABIN, O., et al., "Nanowires and nanotubes", Materials Science and Engineering, v.23, pp.129-140, Jan. 2003.

[22] KIM, G.S., SEO, H.K., GODBLE, V.P., et al., "Electrophorect deposition of titanate nanotubes from commercial titania nanoparticles: Application to dye-sensitized solar cells", Chonbuk National UniversityKorea, 2006.

[23] KASUGA, T., "Formation of titanium oxide nanotube", American Chemical Society Langmuir, v.14 n.12, pp. 3160-3163, May 1998.

[24] NEILSON M. S., JARDEL, M. R., JOSE, M. E. M., et al., "Alkali metal intercalated titanate nanotubes: Metal cations intercalated titanate nanotubes as catalysts for $\alpha, \beta$ unsaturated esters production", Applied $\mathrm{Ca}$ talysis A, v. 454, pp. 74-80, Mar. 2013.

[25] BARTOLOMEU, C. V., ODAIR, P. F., ANTONIO, G. S. F., et al., "Highlighting the mechanism of the titanate nanotubes to titanate nanoribbons transformation", J Nanopart Res, v.13, pp. 3259-3265, Aug. 2011.

[26] SCHMIDT, M. L., BACH, U., HUMPHRY, B. R., et al., "Organic dye for highly efficientsolid-state dye-sensitized solar cells", Advanced Materials, v. 17, pp. 813, Apr. 2005.

[27] CHANG, Y.J., CHOW, T.J., "Highly efficient triarylene conjugated dyes for sensitized, solar cells", Journal of Materials Chemistry, v. 21, pp. 9523, Feb. 2011.

[28] LU, L. L., ERIC, W. G. D., "Porphyrin-sensitized solar cells", Chemical society reviews, v. 42, pp. 291304, oct. 2012.

[29] DMITRY V. B., FRANK C. WALSH., Titanate and Titania Nanotubes Synthesis, Properties and Appli- 
cations., School of Engineering Sciences, University of Southampton, Southampton-UK, ed. 12, Royal Society of chemistry, 2010.

[30] CAMPBELL, W.M., JOLLEY, K.W., WAGNER, P., et al., "Highly efficient porphyrin sensitizers for dye-sensitized solar cells", Journal of Physical Chemistry C, v.111, pp. 11760-11762, Jun. 2007.

[31] CID, J., YUM J., JANG, S., NAZEERUDDIN, M.K., et al., "Molecular co-sensitization for efficient panchromatic dye-sensitized solar cells", Angewandte Chemie International Edition, v.46, pp. 8358-8362, 2007.

[32] DAILY, S., "Ultrathin, Dye-sensitized Solar Cells Called Most Efficient To Date", American Chemical Society, Sept. 2006.

[33] ECOLE, P. F. L., "New Efficiency Benchmark For Dye-sensitized Solar Cells", ScienceDaily, Nov. 2008.

[34] MELE, G., ROBERTA, S., GIUSEPPE, V., et al., "Polycrystalline $\mathrm{TiO}_{2}$ impregnated with cardanolbased porphyrins for the photocatalytic degradation of 4-nitrophenol", Green Chem., v. 6, pp. 604-608, Oct. 2004.

[35] CARIOCA, J. O. B., VASAPOLLO, G., MELE, G., et al., "Cardanol Separation from CNSL: Problems and Perspectives", In: 1 Brazilian Workshop of Green Chemistry, v. 1, Fortaleza 2008.

[36] CLEMENTE, C.S., RIBEIRO, V.G.P., SOUSA, J.E.A., et al., "Porphyrin synthesized from cashew nut shell liquid as part of a novel superparamagnetic fluorescence nanosystem", J. Nanoparticle Res., v. 15, pp. 1739, May 2013.

[37] BARTOLOMEU, C. V., ODAIR, P. F., ANTONIO, G. S. F., et al., "Structural, Morphological and Vibrational Properties of Titanate Nanotubes and Nanoribbons", J. Braz. Chem. Soc., v. 20, n. 1, pp.167-175, 2009.

\section{ORCID}

Antonio Paulo Santos Souza

Ana Fabíola Leite Almeida

Leila de Souza Conegero

Bartolomeu Cruz Viana

Odair Pastor Fereira

Francisco Klayton Marques de Alencar

Selma Elaine Mazzetto

Pierre Basílio

Manuel Pedro Fernandes Graça

Francisco Nivaldo Aguiar Freire https://orcid.org/0000-0001-8518-0503

https://orcid.org/0000-0002-8867-5453

https://orcid.org/ 0000-0001-8023-2028

https://orcid.org/0000-0002-5207-4269)

https://orcid.org/0000-0001-8274-5222

https://orcid.org/0000-0003-1860-4841

https://orcid.org/0000-0002-6879-3209

http://orcid.org/0000-0002-7822-2354

https://orcid.org/0000-0002-6858-9507

https://orcid.org/0000-0001-5449-2635 